\title{
José Guadalupe Posada: el legado póstumo de un artista
}

\section{Flor Aguilar Manjarrez}

E1 arte como un medio de expresión cumple su cometido al transmitir y comunicar los sentimientos del artista que realiza y da vida a su obra. El artista, más allá de su creatividad y talento, se convierte simultáneamente en la voz de un pueblo, cumpliendo así una función social y, por ende, logrando un cambio en la idiosincrasia de la sociedad de un país. De esta manera, el artista transforma el arte en su más poderoso canal de comunicación.

Hablar de Guadalupe Posada, es hablar de más de un periodo en la historia política y social de México, de la vida cotidiana de sus habitantes, de su extraordinario talento y del legado que deja al construir los cimientos para el desarrollo del arte contemporáneo en el país. Aunque poco se conoce de la vida personal de José Guadalupe Posada, es evidente su pasión, dedicación y gran amor por el arte. Se sabe que nace un día 2 de Febrero de 1852, en la provinciana ciudad de San Marcos, en Aguascalientes. Fue hijo de Germán Posada y Petra Aguilar quienes procrearon, a su vez, tres varones más y una hembra. Se dice que contrajo nupcias con Jesús Vela, oriunda de León, Guanajuato con la que desafortunadamente no logró descendencia alguna. Es una relación extramarital la que cumpliría a Posada su deseo de convertirse en padre. Sin embargo, para infortunio del artista, su unigénito muere a muy corta edad.

Su destreza y habilidad para el grabado le abren nuevos horizontes y, con ello, la oportunidad de trabajar para Trinidad Pedroso, experimentado maestro en el arte de la litografía, quien comparte su sapiencia y conocimientos en la materia con el joven artista. El talento de Posada va más allá del grabado, la facilidad que posee en el manejo del lápiz le abre las puertas en el mundo del periodismo como dibujante, dando a luz a sus primeras viñetas ("es cada uno de los recuadros de una serie en la que con dibujos y texto se compone una historieta") en el periódico El Jicote, en el año de 1871. La espontaneidad, gracia y humor del artista para ilustrar ciertos temas sobre la política de México perturbaron a más de uno, enviándole al destierro junto con su gran maestro, Trinidad Pedroso, dueño y editor del taller donde Posada dio muestra de su innato don como caricaturista. En busca de nuevos horizontes ambos deciden emigrar a la ciudad de León, Guanajuato, dejando el pasado y la política en el baúl de los recuerdos. Dándole un nuevo rumbo a su carrera, ambos convienen en dedicarse a la elaboración de diversos e ingeniosos diseños. Al mismo tiempo, Posada combina su trabajo artístico con la docencia, trabajando como maestro en la "Escuela de Instrucción Secundaria", al parecer alrededor de 1884 y 1988. Posada iniciaría de nuevo el éxodo hacia la 
ciudad de México, donde abriría su propio taller, y se le presentaría una vez más la oportunidad de trabajar para reconocidas casas editoriales, como la de Irineo Paz escritor y abuelo del célebre Octavio Paz. Posada hace gala una vez más de destreza artística, ilustrando así para los más importantes periódicos de aquella época, como El Ahuizote, Revista de México, La Patria Ilustrada, El Fandango, La Guacamaya, La Gaceta de Holanda y muchos otros más.

En la Gaceta Callejera, "hoja volante que se publicará cuando los acontecimientos de sensación lo requieran", propiedad y creación de Vanegas Arroyo, Posada da rienda suelta a su creatividad, imprimiendo en cada una de sus páginas un retrato hablado del México de aquellos años. En sus páginas se informaba al público de todo aquello que sucedía en el país, regalando a sus lectores, además de sus letras, un reportaje picaresco y una variedad de viñetas que el artista dibujaba con gran realismo, destreza y comicidad. Nada ni nadie se escapaba del hechizo de su lápiz. Además de las noticias del día, también se deleitaba a los lectores con viñetas alusivas a otros temas, que resaltaban por el gran realismo expresado en ellas y la gran dosis de entretenimiento y diversión que proporcionaban a sus lectores. Los temas eran variados y un tanto chuscos, sensacionalistas, aderezados con una pizca dantesca como éstos: "El horroroso crimen del horroroso hijo que mató a su horrorosísima madre", "Tristísimas lamentaciones de un enganchado", "Terribles crímenes de hacendados", "Terribles y espantosísimos estragos habidos por la suma escasez de semillas"; este otro: "Manifestaciones antirreeleccionistas", despertando así la curiosidad y también el enojo del que los leía. Hubo más de un servidor público que lo vio con desagrado, lo que costó a Posada varias visitas a la cárcel. El artista retorna a los temas religiosos, como las "estampas que contienen oraciones e imágenes de vírgenes y santos"; los juegos de mesa, como el "Juego de la Oca" que alguna vez jugamos cuando éramos niños; portadas para libros, como el recetario que la abuela usaba cuando cocinaba; y almanaques, así como los tan populares e inolvidables cancioneros, deleite de viejos y niños.

Versátil, inquieto y creativo, Posada se estrena como ilustrador en la meca del teatro engalanando con sus singulares dibujos las pastorelas, cuplés y zarzuela las marquesinas de los teatros. Sin dejar atrás la música, dio vida al corrido ilustrando con singular picardía "los defectos y virtudes" de sus protagonistas. No podía faltar la muerte, el sueño eterno, la prolongación. El final de una vida terrenal y el comienzo de la vida eterna, la muerte de la que nadie escapa. La muerte tilica y flaca, la calavera proletaria, francachela burlona y parrandera. La Catrina de ciudad sombreruda y elegante, presumida y arrogante, la calavera burguesa. Cambio, época de conflicto, a Posada le toca vivir una gran parte de la historia de México. Es la muerte en 1913 quien lo rescata de un gobierno dictador, de la inestabilidad y el caos.

Hay quienes afirman que la obra de Posada se podría resumir en tres periodos y que éstos están entrelazados estrechamente con las técnicas usadas por el artista para la realización de sus grabados. Posada se proyecta como maestro indiscutible del buril, su "grabado en hueco, sobre metal tipográfico y al ácido sobre zinc", lo hacen único, y lo proclaman amo y señor del arte, dueño absoluto de su incomparable creación. Su vida, como su obra, está pintada en blanco y negro, como el día y la noche, salpicada de claroscuros. Trazos firmes, genio de la forma y la perspectiva, juega, crea, imagina y se convierte en padre de la caricatura mexicana.

Posada es un nombre perfecto, pues en él se funden todos los elementos que conforman el arte mismo. 
En los miles de grabados encontrados queda la huella imborrable del artista que dio vida al arte moderno en México. Su obra es una recopilación, un compendio de la vida cotidiana y folclórica de México, de su historia y sus personajes. Posada no condena, no critica ni censura, su obra no es una fábula de Esopo, no contiene una moraleja, sólo intenta entretener y divertir a la gente de un país, ya de por sí explotado y en decadencia.

Hay quienes con tristeza comentan que el nombre del artista será olvidado por el mexicano, pero Posada vive, está presente en la vida cotidiana. Está en la caja de cerillos que utiliza el pobre en la cocina para prender una vela, en la estampa de la virgen que se venera en la fábrica, donde trabaja la prole. Está visible, latente: es la cara de la muerte burlona y arrogante, la calavera de azúcar que lleva en su frente el nombre del amigo y del pariente. Es el papel de china con que se adornan los altares en el Día de muertos; el juego de lotería de la feria del pueblo. Su obra es la cara de la burguesía y del proletariado. Es la conciencia del político corrupto, el amigo parrandero y burlón de la muerte, "Ciudadano de la calle", juglar y voz del pueblo.

El nombre de Posada al igual que sus grabados queda impreso, tatuado en el recuerdo de la historia del arte contemporáneo de México. Su buril fue el instrumento con que grabó la historia de la vida costumbrista y folclórica de México. Hijo predilecto de las artes, su obra es inspiración para las nuevas generaciones en el arte del grabado.

Su vida como su obra estuvo llena de claroscuros, en ella se combinaron todos los elementos del arte. Posada, trazo único y perfecto, buril que marca, que deja huella en la historia. Cronista, juglar que compone, que narra la vida de pobres y ricos en sus grabados y dibujos. En suma, psicólogo del pueblo, que analiza la historia y la convierte en arte.

Ilustrador, caricaturista, amigo de la muerte, Posada retrata su esencia y la convierte en aliado del mexicano que, temeroso, se burla, juega y baila con ella. Su trazo es único y perfecto, difícil de superar, imposible de replicar.

Y aunque tristemente no pudo brillar en su tiempo, el arte popular de Posada quedará para siempre grabado en el corazón de los mexicanos: su obra al igual que su vida es parte de su legado. Es el legado póstumo de un artista para la gente, el pueblo al que Posada vigila y guarda desde la eternidad.

Dicen que a Posada y la Catrina

se les ve muy juntos en las cantinas

publicando sus viñetas con sarcasmo

y celebrando con tequila, los trinquetes y desfalcos

de Peña Nieto y su equipo prísta. 


\section{Bibliografía}

"Posada, más que una Calavera". Aguascalientes celebra los 100 años de Posada. Aguascalientes, Gobierno del Estado. Web. 21 Feb. 2017. 